\title{
CLINICAL EVALUATION OF PATIENTS WITH VANCOMYCIN SPACER RETAINED FOR MORE THAN 12 MONTHS
}

\section{AVALIAÇÃO CLÍNICA DE PACIENTES COM ESPAÇADOR DE VANCOMICINA RETIDO POR MAIS DE 12 MESES}

\author{
Leonardo Kurebayashi ${ }^{1}$, Adauto Telino de Melo Junior ${ }^{1}$, Fernando Brandão Andrade-Silva ${ }^{1}$, Kodi Edson Kojima ${ }^{1}$, \\ JORGE DOS SANTOS SILVA 1
}

1. Universidade de São Paulo, Faculdade de Medicina, Instituto de Ortopedia e Traumatologia, São Paulo, São Paulo, Brazil.

\section{ABSTRACT}

Objective: There is no consensus in the literature regarding the time taken to remove antibiotic spacers in the treatment of bone infections. The aim of this study is to evaluate the clinical results of patients with prolonged retention of the same. Methods: Patients selected were diagnosed with post-osteosynthesis infection and/or osteomyelitis and were submitted to treatment using an orthopedic cement spacer (polymethylmethacrylate) with vancomycin, retaining it for a period of more than 12 months. They were clinically evaluated to determine the presence of local or systemic infectious signs via hemogram, investigations of inflammatory markers, liver, renal and, with radiographic control. Results: Eighteen patients were included in the study. The mean retention time of the spacer was 30.4 months (15- 61 months). No patient had clinical signs of local or systemic infectious relapse at the time of evaluation. Seven patients (39\%) presented non-disabling pain in the operated limb. Seventeen patients (94\%) presented a reduction in C-reactive protein values compared to the preoperative period. Radiographically, no migration, no spacer failure, or bone sequestration occurred. Conclusion: In this retrospective case series, cement spacer retention with vancomycin for more than 12 months was associated with good clinical results, without relapse of the infectious condition. Nível de Evidência IV. Estudos Terapêuticos - Investigação dos Resultados do Tratamento.

Keywords: Osteomyelitis, Polymethyl Methacrylate, Anti-Bacterial Agents.

\section{RESUMO}

Objetivos: Na literatura não há consenso em relação ao tempo para a retirada dos espaçadores com antibiótico no tratamento das infecções ósseas. O objetivo deste estudo é avaliar os resultados clínicos de pacientes com retenção prolongada dos mesmos. Métodos: Foram selecionados pacientes com infecção pós-osteossíntese e/ou osteomielite submetidos a colocação de espaçador de cimento ortopédico (polimetilmetacrilato) com vancomicina que retiveram o mesmo por período superior a 12 meses. Os pacientes foram avaliados clinicamente quanto à presença de sinais infecciosos locais ou sistêmicos, laboratorialmente com hemograma, marcadores inflamatórios, função hepática, renal e radiograficamente. Resultados: Dezoito pacientes foram incluídos no estudo. O tempo médio de retenção do espaçador foi de 30,4 meses (15 a 61 meses). Nenhum paciente apresentou sinais clínicos de recidiva infecciosa local ou sistêmica no momento da avaliação. Sete pacientes (39\%) apresentaram dor não incapacitante no membro operado. Dezessete pacientes (94\%) apresentaram redução nos valores da proteína $C$ reativa comparativamente ao período pré-operatório. Radiograficamente, não houve migração, falha do espaçador ou identificação de sequestro ósseo em nenhum caso. Conclusão: Nessa série de casos retrospectiva-a retenção do espaçador de cimento com vancomicina por mais de 12 meses foi associada a bons resultados clínicos, sem recidiva do quadro infeccioso. Level of Evidence IV. Therapeutic Studies Investigating the Results of Treatment.

Descritores: Osteomielite. Polimetil Metacrilato. Antibacteriano.

Citation: Kurebayashi L, de Melo-Junior AT, Andrade-Silva FB, Kojima KE, Silva JS. Clinical evaluation of patients with vancomycin spacer retained for more than 12 months. Acta Ortop Bras. [online]. 2019;27(1):55-8. Available from URL: http://www.scielo.br/aob.

\section{INTRODUCTION}

In orthopedic surgery, the use of polymethylmethacrylate (PMMA) bone cement has proven effective in stabilizing implants and filling dead space created in the treatment of infection after osteosynthesis $^{1}$. In 1970, Buchholz and Engelbrecht were the first to describe their use associated with antibiotics ${ }^{2,3}$ followed by publications showing the efficacy of this association in the treatment of orthopedic infections $s^{1,4,5}$. Its advantages compared to oral or intravenous antibiotic therapy include the release of local antibiotics in higher concentrations, relative lower serum level, and consequent reduction in toxicity associated with the use of systemic antibiotics ${ }^{6}$.

There is no consensus in the literature regarding the time for the removal of the spacer, and few studies describe the effects of its retention in the long term. The main disadvantage of the use of cement is the need for a second surgery for its removal since the reduction in antibiotic concentration over time could favor local bacterial proliferation and biofilm formation ${ }^{1-3,7}$. However, some authors have described patients with spacer retention for up to

All authors declare no potential conflict of interest related to this article.

\footnotetext{
Study was conducted at the Universidade de São Paulo, Faculdade de Medicina, Instituto de Ortopedia e Traumatologia, São Paulo, São Paulo, Brazil.

Correspondence: Leonardo Kurebayashi. Hospital das Clínicas, Faculdade de Medicina, USP. Rua Dr. Ovídio Pires de Campos, 333, Cerqueira César, São Paulo, São Paulo, Brazil. 05403-010. leo.kure@gmail.com
} 
76 months without significant clinical repercussions ${ }^{8}$. At present, there is no consensus on the safety and effectiveness of retention of cement spacers for prolonged periods.

The objectives of this study included the evaluation of the clinical results of patients with spacer for more than 12 months, the laboratory evaluation of inflammatory and infectious tests, and their radiographic evaluation.

\section{MATERIALS AND METHODS}

This study consists of a series of retrospective cases and was conducted at a tertiary health service with the approval of the Research Ethics Committee (78931417.3.0000.0068). Patients with an infectious condition after a fracture fixation and/or acute or chronic osteomyelitis were selected and subjected to the placement of a cement spacer with vancomycin.

Patients were selected for this study on a voluntary basis and signed an informed consent form. Selected participants, all aged between 18 and 65 years, had a history of osteomyelitis or a diaphyseal fracture of the femur, tibia or humerus, and were operated between January 2012 and December 2016. Those patients had undergone surgical treatment with the use of a spacer (PMMA) and antibiotic (vancomycin), within a minimum postoperative time of 12 months. They were invited to undergo clinical, laboratory and radiographic evaluation. We excluded patients who showed signs of clinical or neurological sequels, as those prevented an accurate evaluation, as well as those who had lost their outpatient follow-up documents. Demographic data, fracture time and location, confirmation of osteomyelitis diagnosis, comorbidities, presence of persistent surgical wound drainage, secondary infections, refractures, seroma formation, possible nephrotoxic and hepatotoxic effects of antibiotic therapy, gastrointestinal effects, thromboembolism, and the presence of surgical wound dehiscence were all analyzed.

The selected patients were invited for clinical, laboratory, and radiographic evaluation. During the consultation, blood samples were collected for laboratory analysis, we then compared the results with those of the exams performed prior to the PMMA placement. Complete blood count, aspartate aminotransferase (AST), alanine aminotransferase (ALT), alkaline phosphatase, gamma-GT, total bilirubin and fractions, albumin, coagulogram, creatinine, urea, and C-reactive protein were analyzed. New radiographs of the anteroposterior and lateral views of the operated limb were requested to evaluate bone changes related to the bone cement spacer (PMMA) and to investigate possible signs of osteomyelitis. Two types of spacers were evaluated in this study: diaphyseal spacers (used in infections of intramedullary rods) and spacers in pearl necklaces (used in commonly-occurring cavitary infections in metaphyseal regions). Intramedullary diaphyseal spacers are made of an internal structure made using Kirschner wire with 2.0 $\mathrm{mm}$ diameter that is manually molded according to the length of the affected bone. The proximal portion of the wire is bent in a loop shape, allowing for the introduction and removal of the spacer. The pearl necklaces are manually molded and connected using a Nylon 0 wire. The mixing time of polymethyl methacrylate powder with the liquid polymer was standardized to $30 \mathrm{~s}$ before the addition of the antibiotic (2 $\mathrm{g}$ of vancomycin for every $40 \mathrm{~g}$ of cement).

Patients were subjected to follow-up exams 1 week, 2 weeks, 4 weeks, 3 months, and 6 months after the procedure, and annually after that. The criteria for defining the last surgery included the absence of secretion or inflammatory signs around the surgical wound and a clinical improvement of pain and laboratory parameters (reduction of CRP and blood count without changes). All patients were discharged with antibiotic therapy guided by the cultures, with a minimum time of 6 weeks of treatment. There was no need for funding for the execution of this project.

\section{RESULTS}

In total, 18 patients met the selection criteria. The mean age was 39.9 (range: $18-61$ ) years; 13 patients (72.2\%) were male and five patients $(27.8 \%)$ were female (Table 1$)$. Half of the patients evaluated had undergone surgery due to Chronic Hematogenous Osteomyelitis, and the other half were operated due to a postoperative infection (Table 2). Five patients (27.8\%) contracted an infection after an automobile accident, three (16.7\%) after falls and one (5.6\%) after a firearm injury. The mean retention time of the spacers was 30.4 months, ranging from 15 to 61 months, with 12 patients (66.7\%) with diaphyseal spacers and six with pearl necklaces (33.3\%). Eleven patients underwent surgery on the femur (61.1\%), six on the tibia (33.3\%), and one on the humerus (5.6\%). Three patients were diagnosed with systemic arterial hypertension (16.7\%) and two with diabetes mellitus (11.1\%). Of the 18 patients, 11 (61.1\%) declared to be social drinkers and three (16.7\%) were smokers.

Table 1. Demographic and clinical characteristics of selected patients

\begin{tabular}{c|c}
\hline & $\mathbf{n = 1 8}$ \\
\hline Age & $39.9(\mathrm{SD} \mathrm{13.75)}$ \\
\hline Gender & $13(72.2 \%)$ \\
\hline Male & $9(27.8 \%)$ \\
\hline Female & $12(66.7 \%)$ \\
\hline Type of spacer & $6(33.3 \%)$ \\
\hline Diaphyseal & $11(61.1 \%)$ \\
\hline Pearl necklace & $6(33.3 \%)$ \\
\hline Region (diaphysis) & $1(5.6 \%)$ \\
\hline Femur & 30.4 months (SD 13.36) \\
\hline Tibia & $3(16.7 \%)$ \\
\hline Humerus & $2(11.1 \%)$ \\
\hline Retention time & $4(22.2 \%)$ \\
\hline Comorbidities & \\
\hline HAS & $11(61.1 \%)$ \\
\hline DM & $3(16.7 \%)$ \\
\hline Other &
\end{tabular}

Abbreviation: SD, Standard Deviation.

\begin{tabular}{c|c|c|c|c|c}
\multicolumn{7}{l}{ Table 2 . Clinical results. } \\
\hline Case & Age & Diagnostic & VAS & Bacteria & PCR $(\mathbf{m g} / \mathbf{L}){ }^{*}$ \\
\hline 1 & 41 & COM & $6 / 10$ & Streptococcus anginosus & $155.0-10.7$ \\
\hline 2 & 52 & COM & $2 / 10$ & S. aureus/S. epidermidis & $329.1-1.6$ \\
\hline 3 & 25 & COM & $0 / 10$ & Serratia marcescens & $53.3-0.7$ \\
\hline 4 & 59 & COM & $0 / 10$ & P. aeruginosa/K. pneumoniae & $7.6-20.9$ \\
\hline 5 & 18 & COM & $0 / 10$ & S. epidermidis & $21.0-1.4$ \\
\hline 6 & 39 & COM & $0 / 10$ & S. aureus/S. epidermidis & $410.6-2.0$ \\
\hline 7 & 31 & COM & $0 / 10$ & S. epidermidis & $108.4-14.2$ \\
\hline 8 & 61 & COM & $0 / 10$ & S. aureus & $17.8-7.5$ \\
\hline 9 & 18 & COM & $0 / 10$ & S. aureus & $94.0-1.5$ \\
\hline 10 & 32 & POI & $6 / 10$ & Staphylococcus lugdunensis & $29.6-1.5$ \\
\hline 11 & 53 & POI & $6 / 10$ & S. aureus & $45.0-1.3$ \\
\hline 12 & 50 & POI & $3 / 10$ & S. aureus & $40.7-3.5$ \\
\hline 13 & 51 & POI & $3 / 10$ & S. aureus & $110.0-21.8$ \\
\hline 14 & 47 & POI & $1 / 10$ & S. aureus & $79.9-11.0$ \\
\hline 15 & 38 & POI & $0 / 10$ & Proteus mirabilis & $8.3-2.1$ \\
\hline 16 & 35 & POI & $0 / 10$ & Peptostreptococcus anaerobius & $95.1-9.3$ \\
\hline 17 & 48 & POI & $0 / 10$ & S. aureus & $13.9-3.0$ \\
\hline 18 & 20 & POI & $0 / 10$ & S. aureus & $271.4-6.3$ \\
\hline
\end{tabular}

Abbreviation: VAS, Visual Analogue Scale of Pain; COM, Chronic Osteomyelitis; POI, Postoperative Infection. * Values in the presence of infection and during outpatient return after 12 months of spacer retention. Reference value: $<5.0 \mathrm{mg} / \mathrm{L}$. 
In cases of chronic hematogenous osteomyelitis, Staphylococcus aureus was the most prevalent bacteria isolated, affecting four patients (44.4\%). Only one patient in this group showed an increase in the C-reactive protein when comparing the results in the presence of infection and during the outpatient return after 12 months of retention. $S$. aureus was also responsible for six postoperative infections (66.7\%), with all cases showing a decrease in the C-reactive protein (Table 2). No change was observed when comparing the results of the other laboratory tests requested (complete blood count, AST, ALT, alkaline phosphatase, gamma-GT, total bilirubin and fractions, albumin, coagulogram). All of the above exam results were within the reference values.

No signs of new fractures of infectious recurrence, such as thickening of the periosteum or bone sequestration, were observed in any of the patients. In fracture cases, Lane and Sandhu's criteria were used, and a maximum score was assigned for each fracture, with total bone formation, absence of fracture line and cortical remodeling.

\section{DISCUSSION}

The primary objective of this study was to clinically evaluate and identify possible late complications (clinical, laboratory or radiographic) of patients with retention of the PMMA spacer with vancomycin after a minimum period of 12 months. The initial hypothesis of the study was that retaining the PMMA spacer with vancomycin for more than 12 months in patients with good clinical evolution and control of local infectious signs can be tolerated by a significant number of patients, without negative clinical repercussions in the long term.

The main disadvantage in the use of PMMA is the need to remove the spacer, as it can act as a growth medium for resistant organisms ${ }^{9}$. One of the pioneering studies on this subject was conducted by Kendall et al. ${ }^{10}$, who analyzed an in vitro model associating acrylic cement with antibiotics. Viable organisms were found in cement after 96 hours and, for this reason, the authors began to recommend the cautious use of cement in clinical practice. However, the combination of antibiotics with PMMA in the treatment of infected or at-risk orthopedic lesions has been shown to reduce infection rates, both in animals and clinical studies ${ }^{5}$. In a retrospective study, Selhi et al. ${ }^{11}$ described the retention of intramedullary implants with bone cement and antibiotics for a period ranging from 6 weeks to 22 months (mean, 10.6 months) with satisfactory results in the treatment of infected non-union fractures. The authors mention studies that retained implants for up to 753 days without any complications other than implant breakage in a single patient. Similarly, Paley et al. ${ }^{12}$ followed-up on patients with intramedullary bone cement and antibiotic implants for a period ranging from 32 to 48 months (mean 40.9 months), without recurrent infections in this interval.

Following the selection criteria, 18 patients with spacer retention with an interval ranging from 15 to 61 months, with a mean of 30.4 months $(S D=13.36)$ were selected. In all cases, the patients chose to remain with the spacers and not to be subjected to a new surgical procedure for their removal. It was found that none of the patients had persistent drainage of the surgical wound, dehiscence of the surgical wound, formation of seroma near the site of bone cement insertion, fever, or thromboembolic episodes. Pain assessment using the Visual Analogue Pain Scale showed that 11 patients (61.1\%) reported no pain in the operated limb. Of the seven patients who complained of continued pain, five (71.4\%) were in the group of patients with postoperative infection secondary to fracture fixation. Trauma and its sequels are possible factors of interference in this evaluation. In the group of patients whose initial infectious condition was caused by hematogenous osteomyelitis ( $n=9$ ), only two (22.2\%) reported pain in the clinical evaluation. The complications described by Lou et al. ${ }^{2}$, such as persistent drainage of content through the surgical wound, infection of the external fixator fixation pin, thromboembolism and recurrent infection, was not observed in any patient.

According to Hake et al. ${ }^{9}$, the preparation of cement with antibiotics can be divided into high- and low-doses categories. High doses correspond to $>3.6 \mathrm{~g}$ of antibiotic for every $40 \mathrm{~g}$ of cement, and low doses correspond to $<2 \mathrm{~g}$ for every $40 \mathrm{~g}$ of cement. Zalavras et al. ${ }^{5}$ also recommend the association of $4 \mathrm{~g}$ of vancomycin for every 40 $\mathrm{g}$ of cement in the treatment of exposed fractures and osteomyelitis. In this study, we used $2 \mathrm{~g}$ of vancomycin for every $40 \mathrm{~g}$ of cement, with the addition of antibiotics being standardized to $30 \mathrm{~s}$ after mixing cement with a liquid monomer, resulting in higher concentrations after six weeks when compared to the method of simultaneous mixing of cement and antibiotics before the addition of liquid monomer ${ }^{13}$. Despite the description of renal failure secondary to the use of antibiotic spacers in patients undergoing total knee arthroplasty ${ }^{14}$, none of our patients showed an increase in serum creatinine levels between preand postoperative levels. Furthermore, liver function was maintained in every patient. As for the levels of C-reactive protein, the values were significantly lower upon outpatient return, except in one patient. This study has some limitations, mainly linked to the fact that we only examined a retrospective series of cases that did not involve a comparison with the control group. Only patients who retained the spacers for a prolonged period with good clinical evolution were analyzed, and no clinical, radiographic and laboratory comparisons were made with those who required new surgical intervention in less than 12 months. Since the cases of treatment failure were not evaluated, it was impossible to evaluate risk factors for unfavorable clinical outcome. Late removal of the spacers to evaluate biofilm formation or bone tissue culture in search of latent infection would add relevant clinical information to this study. Similarly, serum vancomycin levels were not measured, which could show the levels of residual concentration of the antibiotic associated with spacer retention.

Despite the limitations of this study, it was possible to demonstrate that patients with antibiotic cement spacers who had favorable clinical signs, with infectious control, remained clinically well with the retention of the spacer for 12 months or longer. No adverse clinical signs, such as pain and local infectious recurrence, or laboratory and radiographic signs of poor prognosis related to the retainment of the spacer were observed. With the findings of this study, we cannot and do not intend to establish a definitive treatment for patients with spacers, nor do we recommend the prolonged retention of spacers as a routine treatment. Comparative observational studies, including patients with negative and positive clinical outcomes, are necessary for the establishment of definitive recommendations. However, the data from this study demonstrate that in patients in whom spacer retention is necessary, the infectious condition can be kept under control, and no complications directly associated with spacer retainment for more than 12 months were identified.

\section{CONCLUSION}

This study showed that patients with vancomycin cement spacers with good clinical evolution throughout more than 12 months could maintain a controlled infectious condition with spacer retention, and no complications or adverse events directly associated with spacer retention were identified.

AUTHORS' CONTRIBUTIONS: Each author contributed individually and significantly to the development of this article. LK (0000-0002-0039-4906)*: article writing, data collection, statistical analysis, and study concept; ATMJ (0000-0003-1593-5346)*: data collection, statistical analysis and study concept; FA (0000-0003-3025-1719)*: study concept and article review; KEK (0000-0001-9543-081X)*: study concept and article review; JSS (0000-0001-8901-3120*: study concept and article review. *ORCID (Open Researcher and Contributor ID). 


\section{REFERENCES}

1. Dusane DH, Diamond SM, Knecht CS, Farrar NR, Peters CW, Howlin RP, et al. Effects of loading concentration, blood and synovial fluid on antibiotic release and anti-biofilm activity of bone cement beads. J Control Release. 2017;248:24-32.

2. McConoughey SJ, Howlin RP, Wiseman J, Stoodley P, Calhoun JH. Comparing PMMA and calcium sulfate as carriers for the local delivery of antibiotics to infected surgical sites. J Biomed Mater Res B Appl Biomater. 2015;103(4):870-7.

3. Oh EJ, Oh SH, Lee IS, Kwon OS, Lee JH. Antibiotic-eluting hydrophilized PMMA bone cement with prolonged bactericidal effect for the treatment of osteomyelitis. J Biomater Appl. 2016;30(10):1534-44.

4. Luo S, Jiang T, Yang Y, Yang X, Zhao J. Combination therapy with vancomycin loaded calcium sulfate and vancomycin-loaded PMMA in the treatment of chronic osteomyelitis. BMC Musculoskelet Disord. 2016;17(1):502.

5. Zalavras CG, Patzakis MJ, Holtom P. Local antibiotic therapy in the treatment of open fractures and osteomyelitis. Clin Orthop Relat Res. 2004;(427):86-93.

6. Swearingen MC, Granger JF, Sullivan A, Stoodley P. Elution of antibiotics from poly(methyl methacrylate) bone cement after extended implantation does not necessarily clear the infection despite susceptibility of the clinical isolates. Pathog Dis. 2016;74(1):ftv103.

7. Kluin OS, van der Mei HC, Busscher HJ, Neut D. Biodegradable vs non-biodegradable antibiotic delivery devices in the treatment of osteomyelitis. Expert Opin Drug Deliv. 2013;10(3):341-51.
8. Elmarsafi T, Oliver NG, Steinberg JS, Evans KK, Attinger CE, Kim PJ. Long-Term Outcomes of Permanent Cement Spacers in the Infected Foot. J Foot Ankle Surg. 2017;56(2):287-90.

9. Hake ME, Young H, Hak DJ, Stahel PF, Hammerberg EM, Mauffrey C. Local antibiotic therapy strategies in orthopaedic trauma: Practical tips and tricks and review of the literature. Injury. 2015;46(8):1447-56.

10. Kendall RW, Duncan CP, Smith JA, Ngui-Yen JH. Persistence of bacteria on antibiotic loaded acrylic depots. A reason for caution. Clin Orthop Relat Res. 1996;(329):273-80

11. Selhi HS, Mahindra P, Yamin M, Jain D, De Long WG Jr, Singh J. Outcome in patients with an infected nonunion of the long bones treated with a reinforced antibiotic bone cement rod. J Orthop Trauma. 2012;26(3):184-8.

12. Paley D, Herzenberg JE. Intramedullary infections treated with antibiotic cement rods: preliminary results in nine cases. J Orthop Trauma. 2002;16(10):723-9.

13. Amin TJ, Lamping JW, Hendricks KJ, Mclff TE. Increasing the Elution of Vancomycin from High-Dose Antibiotic-Loaded Bone Cement. J Bone Joint Surg Am. 2012;94(21):1946-51.

14. Dovas S, Liakopoulos V, Papatheodorou L, Chronopoulou I, Papavasiliou V, Atmatzidis $\mathrm{E}$, et al. Acute renal failure after antibiotic-impregnated bone cement treatment of an infected total knee arthroplasty. Clin Nephrol. 2008;69(3):207-12. 